\title{
The Relationship between assertive social skills and friendship quality of children with disability in Indonesian elementary schools
}

\author{
*Kurniawati F, Universitas Indonesia, farida1@ui.ac.id, ORCID: 0000-0002-8484-4790 \\ Rahadianty A, Universitas Indonesia, acid.rahadianty@gmail.com, ORCID: 0000-0003-2246-0393 \\ *corresponding author
}

\begin{abstract}
The purpose of this study was to determine whether there is a relationship between assertive social skills and the friendship quality of children with disability. A total of 84 students from 20 public elementary schools in the city of Jakarta were involved in this study. Data collection used the Social Skills Inventory Scale (SSIS) to measure assertive social skills, while the Friendship Quality Questionnaire (FQQ) was used to get a picture of the friendship quality. The results showed a significant positive relationship between assertive social skills and friendship quality in children $(r=.321, p<.01)$. It was also found that there were differences in the scores of friendship quality between boys and girls in the dimensions of Help and Guide and Companionship and Recreation. For further research it is recommended to use different data collection methods (eg observation, interviews) and to measure the research variables from the viewpoint of significant others (eg teachers, parents). The involvement of participants with various types of disabilities is also recommended.
\end{abstract}

Keywords: Assertive social skills, friendship quality, disability, elementary school

Received: 13.11.2020 Accepted: 05.12.2020 $\quad$ Published: 10.01.2021

\section{INTRODUCTION}

To realize an equal opportunity of education for children with disability, an inclusive education system is implemented (UNICEF, 2011). UNICEF (2011) defines it as an educational institution involving everyone such as children with serious problems and disabilities, which aims to respect differences, support the learning process, and respond to individual needs. It is also an effort to realize a "school for all". In the international realm the movement on inclusive education systems was announced in the Salamanca Declaration and Framework in 1994. The declaration emphasized the recognition of the importance of seeking "schools for all", with all the differences and responding to individual needs (United Nations, 1994). Delegations from various countries agreed on the contents of the Salamanca declaration to realize education for all, recognizing the importance of providing educational facilities for children, youth and adults with disabilities (United Nations, 1994).

In Indonesia the right to obtain educational opportunity for people with disability is regulated in Law number 8 of 2016 concerning people with disabilities, the sixth part of article 10 concerning the Right to Education. The law outlines that persons with disability are entitled to get quality education at all levels, as well as to get proper education facilities. Regulations regarding the importance of equitable education for all groups encourage the emergence of educational efforts for children with disability by developing an education system designed according to the children's needs. The movement regarding the inclusive education system in Indonesia was officially declared at the National Workshop in 2004 in Bandung which requested that the government and the community enable to guarantee that every child with disability gets a quality education in line with the potential and demands of the community (Hadis, 2005). In 2009, a regulation on inclusive education for students with special needs (or children with disability) was enacted which was published in Regulation of the Minister of National Education of the Republic of Indonesia number 70 of 2009 (MP National, 2009). One of the regulations reads that with inclusive education system children with special needs or children with special talents have the opportunity to attend education in the same environment as regular children.

The inclusive education system is also one of the strategies to form an inclusive society that opposes segregation to create human rights, justice, and equality of individual rights (Suleymanov, 2015; Bunch \& Valeo, 2004). In addition, in the future children with disability are expected to be able to socialize with the community, so that by being exposed to an inclusive environment early, children with disability will become more independent in the future. This is in accordance with The Four Pillars of Learning (Nan-Zhao, 2005) which states that one of the main pillars in education is learning to live 
together in society.

Inclusive education has many benefits for students. Some experts believe that inclusive education will improve students' academic abilities and social skills (Bunch \& Valeo, 2004; Buysse, Goldman, \& Skinner, 2015). According to some studies, children with disability who attend regular schools with inclusive settings can have better academic performance than those who attend special school, especially in language and math skills (Ruijs, Peetsma, \& van der Veen, 2010; Peetsma ,Vergeer, Roeleveld, \& Karsten, 2001). The presence of regular children in inclusive classrooms makes children with disability motivated to perform more, and children with disability can learn more from children without disability (Ruijs, Peetsma, \& van der Veen, 2010). In the social aspect, inclusive education seeks to increase social participation in children with disability as well as supporting meaningful friendship relationships between students without disability and student with disability (de Boer, Pijl, Post, \& Minnaert, 2013; Buysse, Goldman, \& Skinner, 2015 ). Social participation in children with disability involves four aspects, which are social interaction, peer acceptance, friendship, and social self-perception (Koster, Nakken, Pijl, \& Van Houten, 2009). This study focused on the social aspects of inclusive education for children with disability, which was on the friendship aspect.

Friendship is defined as a mutual relationship between two or among more people who like each other and have a bond between the two parties, often spending time together and often engaging in an activity together, and all parties have a positive affect on each other (Hollingsworth \& Buysse, 2009). Friendship provides many benefits such as warmth, affection, and intimacy (Bollmer et al., 2005). Some studies have proven that by having friends, children who have friends will have a better psychological condition than those who do not have friends (Wiener, 2002). Furthermore, having friends can enhance cognitive development and language (Buysse, Goldman, \& Skinner, 2015) and develop positive attitudes towards school (Denham, 2006).

Additionally, the friendship quality is also a more important aspect than just the quantity of having friends (Bollmer et al., 2005; Locke, Ishijima, Kasari, \& London, 2010). Having a high quality of friendship at the age of middle childhood will affect the success of social adjustment in the later stages of development (Sullivan et al, 2012). According to Parker and Asher (1993) the quality of friendship is defined as the level of friendship and support provided by a friendship relationship and also the level of conflict they face. Good quality friendship can increase self-esteem in children, make children have good social and emotional adjustment, and is good for children's cognitive development (Sullivan et al, 2012).

In children with disability in inclusive settings, high quality friendships can be a protective factor from acts of abuse often directed at such children (Bollmer et al., 2005; Crawford \& Manassis, 2011). When the quality of friendships in children with disability is low, they tend to experience internalizing problems where emotional problems such as sadness are directed inward causing depression (Sullivan, et al., 2012). Besides ,the low quality of friendship will lead to social competence that is not good (Crawford \& Manassis, 2011). The explanations above illustrate the importance of paying attention to the quality of friendship in children with disability.

As explained above, one of the main aspects of inclusive education is the friendship that exists among students (Bunch \& Valeo, 2004). Inclusive education will succeed when there is a friendship relationship among students with and without disability (Bunch \& Valeo, 2004). It is the fact that the presence of children with disability in inclusive settings often risks them from getting rejection from peers (Boer, Pijl, Post, \& Minnaert, 2013; Buysse, Goldman, \& Skinner, 2015), difficulties in making friends or even facing violence from peers (Çifci \& Sucuoğlu, 2003; Gülay, 2010). Pijl, Frostad, and Flem's research (2008) shows that as many as 30 percent of children with disability have fewer friends than those without disability. Meanwhile, research by Chang, Shi, and Kasari (2016) has found that only 20\% of children with autism are able to make friends and enjoy playing with their peers. In fact they are left alone and eventually tend to interact only with their friends who are equally disabled (Guralnick, 1995; Pijl, Frostad \& Fleming, 2008). This can be due to negative attitudes of children without disability to their friends with disabilities (de Boer, et al., 2013) or due to limited social and communication skills of children with disability (Heiman, 2000; Crawford \& Manassis, 2011; Odom, 2006). Other causes include lack of ability of children with disability to show prosocial behavior and to collaborate with friends (Ozokzu, 2018), lack of ability to adjust (Richardson \& Schwartz, 2004) and low self-esteem (Han \& Kemple, 2006).

A factor influencing children ability to develop and maintain friendship quality is assertive social skills (Gresham \& Elliot, 2008). Gresham and Elliot (2008) define assertive social skills as the ability to initiate doing something, such as asking others for information, introducing themselves, responding to other people's actions, and asking for help when in need of help. Assertive social skills are fundamental social skills that can support all aspects of life and are the key to success (Wood \& Mallinckrodt, 1990; Cook, 2011). Children who have good assertive social skills will have the ability to resolve conflicts better, 
tend to be easier to make friends, have close friendships and support each other (Crawford \& Manassis, 2011). For children with disability, especially those who learn in inclusive schools, assertive social skills are needed so that they can express themselves and express their intentions and goals to others more precisely (Keser \& Barlas, 2016). The existence of this ability also makes them more accepted in the social environment (Rubin, Bowker, \& Kennedy, 2006; Wojnilower \& Gross, 1988) to reduce rejection and to encourage acceptance among their peers. With this skill the quality of their interpersonal relationships can be better (Cook, 2011). On the other hand, difficulties in displaying assertive social skills can have an impact on the low quality of friendship and can even cause problems in friendship (Allen, 2006). As a result, the individual feels isolated and withdraws from the social environment (Keser \& Barlas, 2016; Rubin, Bowker, \& Kennedy, 2006).

In addition, several studies show that assertive social skills also contribute to academic achievement (Ghodrati, Tavakoli, Heydari, \& Akbarzarech, 2016). A research on high school students in India shows a significant relationship between assertive social skills and academic achievement (Ghodrati, et al., 2016). This is supported by de Miguelsanz, Carbonero Martin, and Palazuelo Martinez (2012) stating that the lack of assertive social skills makes students avoid interaction with their teachers or other students, so they tend to experience difficulties in academic matters. Thus, assertive social skills have benefits from both social and academic aspects.

The quality of friendship in children with disability is influenced by the type of their disability. The results of Bauminger, Solomon, and Rogers' (2010) research conducted on 44 children with ASD at the age of 8-12 years stated that children with ASD are associated with the low friendship quality. In children with ASD and intellectual disability their friendship quality is classified low because they have weakness in social competence and communication skills (Wiener \& Tardif, 2004; Smith \& Matson, 2010). Besides, children with learning disability have difficulty starting and maintaining good friendship quality (Bauminger, Edelsztein, \& Morash, 2005; Kavale \& Forness, 1996). This is similar to the study of Wiener and Tardif (2004) stating that children with learning disability are less involved in mutual friendship relationships, have lower levels of friendship quality, social acceptance, and social skills as well as behavioral problems and higher levels of loneliness than those without learning disability.

Gender also influences friendship quality. Bukowski, Hoza, and Boivin (1994) have developed a measure of the quality of friendship with participants ranging from grades 5,6 , and 7 . The results say that female participants had higher scores than men. This can be interpreted that gender differences have an influence on the quality of friendship. The similar result is also found in the study of Parker and Asher (1993). To sum up, gender has an influence on the quality of friendship.

Previous studies of the extent to which assertive social skills affect the friendship quality on regular children were mostly conducted in western cultures, but similar studies on children with disability are still very limited, especially in eastern cultures in Indonesia. Eastern culture characterized by collectivism can color the relationship between assertive social skills and friendship quality. This increasingly seems furged to be investigated at the elementary school level which is a period where children develop the basic skills to interact and work with people from diverse backgrounds. Friendship is a vital aspect in the development of children in middle age (Sullivan, et al., 2012). Based on this description, this study aims to answer the following question: Is there any relationship between assertive skills and the friendship quality in children with disability in elementary schools?

\section{METHODS}

\section{Research Design}

This research was a correlational study that saw the relationship between two variables, which were assertive social skills as the independent variable and friendship quality as the dependent variable. This research was included in non-experimental research because there was no manipulation of the two variables.

\section{Participants}

A total of 84 participants was involved in this study. They came from 20 elementary schools in Jakarta, the capital of Indonesia. They were at most 11 years old with a percentage of $33 \%(n=28)$, and boys with a percentage of $64 \%(n=54)$. The type of disability in this study was dominated by the participants with slow learners and mild intellectual disabilities with a percentage of $56 \%(\mathrm{n}=47)$. This study was approved by the Review Board of the Faculty of Psychology, Universitas Indonesia. After the ethical review process was complete, data collection began by asking a written permission from the targeted schools. All participants submitted written informed consent. 


\section{Instrument}

To measure the relationship between assertive social skills and friendship quality, the researchers used two measuring instruments which were the Social Skills Improvement System (SSIS) developed by Gresham and Elliot (2008) and Friendship Quality Questionnaire (FQQ) developed by Parker and Asher (1993). SSIS was used to measure the social skills assertive variable while the FQQ was used to measure the friendship quality variable. Gresham and Elliot (2008) divide social skills into seven dimensions: communication, cooperation, assertiveness, responsibility, empathy, participation, and self-control. In order to measure only assertive skills, the researchers just used one dimension on the SSIS, assertive dimensions. We adapted both of the instruments in order to fit the characteristics of children with disability.

The adaptation process to the SSIS resulted in a reduction in the number of items and simplification of statements to make them easier to understand and avoid the effects of fatigue in children with disability. The reliability test results showed that the assertive dimension had an Alpha coefficient of 0.735. All items on the assertive social skills dimension also had a CRIT value above 0.3 , meaning that there were no items to be removed. The SSIS consists of 24 items using a Likert scale from A to D (A = "Not True", B = "Not Always True", C = "True", D = "Very True"). Score 1 is given to point A, and score 4 to point $\mathrm{D}$. The mean value of the SSIS is 2.5. The total score obtained indicated the level of assertive social skills in the participants.

Parker and Asher (1993) developed a tool to measure the quality of friendship called the Friendship Quality Questionaire (FQQ). FQQ consists of 6 dimensions, which are intimate exchange, conflict resolution, companionship and recreation, help and guidance, validation and caring, and conflict and betrayal. Initially the FQQ consisted of 47 items, but after being adapted and a pilot study was conducted only 25 items were used. The reliability test results on the FQQ produce Chronbach's Alpha of 0.808. According to Kaplan and Saccuzo (2005) the value of the reliability coefficient of a good gauge is above 0.7. FQQ takes the form of self-report using a Likert scale from A to D (A = "Not True", B = "Not Always True", C = "True", D = "Very True"). Score 1 is given to point A, and score 4 is given to point $\mathrm{D}$. The mean value of the SSIS is 2.5. The total scores obtained from all dimensions indicate the level of friendship quality of the participants.

\section{Data Analysis}

This study used a statistical analysis method, namely descriptive statistics and Pearson correlation. Descriptive statistics was used to find out the general description of participants including the percentage of age, gender, and type of disability and the mean score of each variable. Meanwhile, Pearson Correlation was used to find out the relationship between the two variables, which were assertive social skills and friendship quality. Data analysis used SPSS version 20.

\section{RESULTS}

This study was aimed to find out the relationship between assertive social skills in children with disability and their friendship quality. The participants' assertive skills and friendship quality scores are categorized into low and high groups by using the midpoint of each of the instrument, which is 2.5. Table 1 presents description of each study variable.

Table 1. Description of assertive social skill scores and friendship quality scores

\begin{tabular}{|l|l|l|l|l|}
\hline Research variable & Minimum Value & $\begin{array}{l}\text { Maksimum } \\
\text { Value }\end{array}$ & Mean & $\begin{array}{l}\text { Standard } \\
\text { Deviation }\end{array}$ \\
\hline Assertive Social Skills & 8 & 25 & 2.65 & .52 \\
\hline Friendship Quality & 48 & 94 & 2.75 & .35 \\
\hline Validation and caring & 1.38 & 3.63 & 2.72 & .48 \\
\hline $\begin{array}{l}\text { Conflict and betrayal } \\
\begin{array}{l}\text { Companionship and } \\
\text { recreation }\end{array}\end{array}$ & 1.00 & 4.00 & 3.08 & .61 \\
\hline
\end{tabular}




\begin{tabular}{|l|l|l|l|l|}
\hline Help and Guidance & 1.00 & 4.00 & 2.78 & .62 \\
\hline Intimate exchange & 1.00 & 4.00 & 2.33 & .69 \\
\hline Conflict resolution & 1.00 & 4.00 & 2.61 & .77 \\
\hline
\end{tabular}

Examine Table 1, it can be seen that the mean of assertive social skills is $2.65(\mathrm{SD}=.52)$. The mean is greater than the midpoint which is 2.5 , so the participants' assertive social skills in general are classified high. The same category is found in general friendship quality $(\mathrm{M}=2.75$; $\mathrm{SD}=.35)$. However, if we look at the dimension per dimension, it is found that the highest mean is on the dimension of Conflict and Betrayal $(\mathrm{M}=3.08 ; \mathrm{SD}=.61)$ and the lowest mean is on the dimension of Intimate Exchange with a mean score of $2.33(\mathrm{SD}=.69)$.

Table 2. Percentage of participants in the assertive social skills and friendship quality categories $(N=84)$

\begin{tabular}{|l|l|l|l|}
\hline \multirow{2}{*}{ Research Variables } & Category & & $\begin{array}{l}\text { High } \\
(\geq 2.5)\end{array}$ \\
\cline { 2 - 4 } & $\begin{array}{l}\text { Low } \\
(<2.5)\end{array}$ & & $55(65.5 \%)$ \\
\hline Assertive Social Skills & $29(34.5 \%)$ & & $63(75 \%)$ \\
\hline Frienship Quality & $21(25 \%)$ & & 6 \\
\hline
\end{tabular}

Table 2 above shows that as many as $65.5 \%(\mathrm{n}=55)$ of the participants have high assertive social skills and $34.5 \%(n=29)$ of the participants have low assertive social skills. In the variable of friendship quality, as many as $75 \%(n=63)$ of the participants have high friendship quality, while as many as $25 \%$ $(\mathrm{n}=21)$ of the participants have low friendship quality.

\section{The Relationship between Assertive Social Skills and Friendship Quality}

The test results to find out the relationship between assertive social skills and quality of friendship using the Pearson correlation analysis are shown in Table 3 below.

Table 3. Pearson correlation analysis between assertive social skills and quality of friendship

\begin{tabular}{|l|l|l|}
\hline Research Variables & Assertive Social Skills & Friendship Quality \\
\hline $\begin{array}{l}\text { Assertive Social Skills } \\
\text { Pearson Correlation } \\
\text { Sig. (2-tailed) } \\
\text { N }\end{array}$ & 1 & $\begin{array}{l}.321^{* *} \\
.003\end{array}$ \\
\hline $\begin{array}{l}\text { Friendship Quality } \\
\text { Pearson Correlation } \\
\text { Sig. (2-tailed) } \\
\text { N }\end{array}$ & 84 & $.321^{* *}$ \\
.003 & 1 \\
\hline
\end{tabular}

\footnotetext{
**. Significantly correlated with ${ }^{* *} \mathrm{p}<0.01(2$-tailed)
}

Based on the results of the analysis in Table 3, there is a significant positive relationship between the variables of assertive social skills and friendship quality $(r=.321, p<.01)$. Thus, the higher the assertive social skills of children with disability, the higher the quality of friendship. With an $r$ value of .321 , a D value of .103 is obtained, so $10.3 \%$ of the variance of friendship quality can be explained by the variance of assertive social skills. 


\section{The Effect of Demographic Variables in the Relationship within the Research Variables}

We conducted an independent sample t-test analysis to determine whether there were differences in the quality of friendship by gender in each of the dimensions of friendship quality. The following are the results of the independent sample t-test analysis test:

Table 4. Differences in friendship quality scores by gender

\begin{tabular}{|c|l|l|l|l|l|}
\hline Research Variables & Gender & $\mathrm{N}$ & Mean & $\mathrm{t}$ & Sig. (2-tailed) \\
\hline Friendship Quality & $\begin{array}{l}\text { Boy } \\
\text { Girl }\end{array}$ & $\begin{array}{l}54 \\
30\end{array}$ & $\begin{array}{l}2.86 \\
2.96\end{array}$ & 2.284 & .023 \\
\hline Validation and caring & Boy & 54 & 2.61 & 1.436 & .155 \\
& Girl & 30 & 2.81 & & \\
\hline Conflict and betrayal & Boy & 54 & 3.06 & 1.437 & .155 \\
\hline Companionship and recreation & Girl & 30 & 3.13 & & \\
\hline Boy & Girl & 34 & 2.23 & 2.155 & .034 \\
\hline Intimate exchange & Boy & 54 & 2.67 & 2.532 & .013 \\
\hline Conflict resolution & Girl & 30 & 3.04 & & \\
\hline & Boy & 54 & 2.75 & .613 & .542 \\
\hline
\end{tabular}

Table 4 shows that girls $(M=2.96)$ have better friendship qualities than boys $(M=2.86)$. Viewed from each of the dimensions, there are significant differences between boys and girls in the Help and Guidance dimension $(\mathrm{t}(82)=2.532, \mathrm{p}<.050)$. It can be concluded that the quality of friendship among girls $(\mathrm{M}=3.04)$ is more involved in helping one another than that among boys $(\mathrm{M}=2.67)$. On the dimension of Companionship and Recreation the scores of boys and girls also have a significant difference $(t(82)=2.155, p<.050)$. In conclusion, the friendship of girls $(M=2.37)$ is more often filled with spending time with friends rather than friendship among boys $(\mathrm{M}=2.23)$.

Different research results were found on the effect of gender on assertive social skills. The results of the independent sample t-test regarding differences in the level of assertive social skills by gender are shown in Table 5 below.

Table 5. Differences in assertive social skill scores by gender

\begin{tabular}{|l|l|l|l|l|l|}
\hline Research Variables & Gender & Amount(N) & Mean & tvalue & Sig \\
\hline Assertive Social skills & Boy & 54 & $\begin{array}{l}2.59 \\
2.75\end{array}$ & 1.36 & .178 \\
& Girl & 30 & & \\
\hline
\end{tabular}

Table 5 shows that there are no significant differences in the scores of assertive social skills between boys and girls $(t(82)=1.36, p>.050)$.

\section{DISCUSSION AND CONCLUSIONS}

Inclusive educations allow children with disability to learn together with other friends without disability in the same school. In order to participate optimally in learning activities, children with disability need acceptance and support from their peers. Unfortunately previous studies have shown that children with disability are less accepted by their peers. Many things are allegedly affecting the friendship quality of children with disability, one of which is social skills. This study wanted to find out the relationship 
between assertive social skills and the quality of friendships in children with disability in primary schools. Children with disability who were participants in the study were asked to fill out two instruments in the form of questionnaires.

The results found out a significantly positive relationship between assertive social skills and friendship quality in children with disability. The results showed that the higher the assertive social skills of children with disability, the higher the quality of friendship. The children with disabilities who were participants in this study had high assertive social skills and high quality friendships. If related to gender, it was found that there were no significant differences between boys and girls on the assertive social skill variable. However, on the quality of friendship, the results showed that girls generally have better friendship qualities than boys. When viewed per dimension, significant differences in the quality of friendship between boys and girls were found in the dimensions of Help and Guidance and Companionship and Recreation.

The results of this study were in accordance with Allen (2006) which says there is a positive relationship between the quality of friendship and assertive skills, where individuals who are less assertive tend to have low friendship qualities because the lack of assertive social skills prevents individuals from engaging fully in friendships leading to the difficulty of maintaining a relationship (Allen, 2006). The results of this study were also in line with the results of previous studies stating that children who are more assertive will be better to find friends and have the ability to resolve conflicts better (Crawford \& Manassis, 2011). Findings from this study showing a positive relationship between assertive social skills and friendship quality were in accordance with the opinions of some experts who say that the difficulty to maintain friendships is influenced by low social skills (Gresham \& Elliot, 2008; Keser \& Barlas, 2016; Rubin, Bowker, \& Kennedy, 2006). In conclusion, the results of this study are in accordance with the results of previous studies.

When viewed from each of the research variables, it was found that the results less consistent with previous studies on assertive social skills variable. In this study assertive social skills in children with disability were classified as high. These results were not in line with the results of Wahyuni (2017). Wahyuni measured the social skills of children with disability through parents perception, and it was found that assertive social skills in children with disability were classified as moderate. Chong and Li (2008) also proved that children with disability, especially children with intellectual disability, have low social assertive skills.

The research results less consistent with previous studies were also found on the variable friendship quality. Overall results from this study indicated that the quality of friendship of children with disability was high. This result is different from the findings of Heiman (2000) saying that children with disability who attend school in inclusive schools have low friendship quality. In line with Heiman (2000), the research showed that children with autism and intellectual disability have low friendship quality because they have weakness in social competence and communication skills (Wiener \& Tardif, 2004; Smith \& Matson, 2010). The similar results were also found in other studies conducted at inclusive schools in Indonesia. Children with disability who study in inclusive schools often experience social isolation and are rejected by peers. Not infrequently they become victims of abuse such as being ridiculed, bullied, and labeled as stupid children by their peers (Poernomo, 2016). The lack of opportunity owned by children with disability to make friends is believed to make them less trained in interaction so that the quality of friendships is low, as found by Hallahan and Kaufman (2006).

Other results from this study indicated that there was no effect of gender on assertive social skills scores. This result did not support the research of Tekinarslan, Çifci, Pinar, Sazak, Sucuoğlu, and Bülbin (2012) who found that social skills in female students with intellectual disabilities were higher than those of male students. Gresham and Elliot (1990) also obtained data that gender differences played a role in the overall level of social skills. Other research results (eg Gülay, 2011; Yoleri \& Seven, 2014) in more detail show that boys are more likely to display aggressive behavior, rarely behave prosocially, are more reactive and have higher scores on aggressive aspects compared to girls. All of these things show the social skills of boys that are relatively low. Meanwhile, significant differences in scores between girls and boys in the two dimensions of friendship quality, namely Help and Guide and Companionship and Recreation might be related to the tendency of girls to be more concerned with emotional aspects in a friendship (Parker \& Asher, 1993).

As many as $56 \%$ of the participants in this study were children who were classified as slow learners and had mild intellectual disabilities. The characteristics of children with this type of disability might explain the difference in scores obtained by the participants. They received the highest score on the Conflict and Betrayal dimensions and the lowest score on the Intimate Exchange dimension. High scores on the dimensions of Conflict and Betrayal signify friendship that is colored by disputes and feelings of annoyance that are quite prominent with peers. This can be related to the characteristics of children with 
intellectual disability, namely their inability to empathize so that they fail to understand the circumstances and needs of others (Hallahan \& Kauffman, 2006). Another explanation could be due to their difficulties in social problem solving and solution generation (Hallahan \& Kauffman, 2006; Siperstein \& Leffert, 1997). Zetlin and Murtaugh also emphasize that children with intellectual disability rarely share stories about personal matters, which in this study were marked by low scores on the Intimate Exchange. Thus, the results of this study indeed adequately illustrate the quality of friendships that are typical in children with intellectual disability who in some previous studies are associated with behavioral problems, social maladjustment, and rejection by peers (Siperstein \& Leffert, 1997). Considering that the majority of participants were children with intellectual disability, the results of this study became difficult to generalize. Future studies are recommended to involve respondents who are more diverse from the type of disability, bearing in mind that different characteristics can affect assertive social skills and the quality of friendship and the relationship between the two.

This research involved children who went to public elementary school. Information about their intellectual disability is not entirely based on the results of examinations from psychologists and medical doctors. Some participants are stated to have the characteristics of slow learners or mild intellectual disabilities based only on information from class teachers whose accuracy could be doubted. In fact, children diagnosed by the teacher may have higher or lower cognitive abilities. If so, then this condition can affect the results of the research obtained. Therefore further research on this matter needs to ensure the clarity and accuracy of diagnosing the disability of children.

This study used a self-report instrument to measure the research variables. The items in this measurement can be misunderstood by participants who experience intellectual disabilities. Therefore, the use of other methods is strongly recommended, such as observation (Chang et al., 2016; Odom et al., 2006) or interviews. In addition, this study looked at the quality of friendship from one party only, namely children with disability, whereas dyadic or bi-directional measurement of friendship will get more in-depth information about friendships (Petrina, Carter, Stephenson, \& Sweller, 2015), so it is necessary to measure the perception of peers about this. In addition, the use of rating scales or interviews with teachers (eg Dietrich, 2005) and parents are expected to be able to get a deeper understanding and more valid data.

Research on children with disability in Indonesia is just beginning to develop, especially relating to friendship. The results of this study can be the reference for professionals to develop assertive social skills training for children with disability so that the quality of their friendship improves and supports other aspects of their life. In addition, by increasing assertive social skills in children with disability, it can also increase the self-esteem of children with disability (Cook, 2011). Seeing the importance of friendship for children with disability, it is recommended for teachers or school parties to try to create a good friendship environment for children with disability. Inclusive schools can be equipped with programs that can improve social relations among children with disability and regular children. As an important figure in the classroom, teachers need to be given ongoing training on effective teaching strategies in supporting friendship among students in schools. The research shows that with teacher support, children with disability can increase social involvement and friendship with peers (Chang et al., 2016; StantonChapman \& Brown, 2015).

\section{REFERENCES}

Allen, J. P. (2006). Leaders and followers in adolescent close friendships: Susceptibility to peer influence as a predictor of risky behavior, friendship instability, and depression. Development and Psychopathology, 18(1), 155-172. https://doi.org/10.1017/S095457940606009

Bauminger, N., Edelsztein, H.S., \& Morash, J. (2005). Social information processing and emotional understanding in children with LD. Journal of Learning Disabilities, 38(1), 45-61.

Bauminger, N., Solomon, M., \& Rogers, S. J. (2010). Predicting friendship quality in autism spectrum disorders and typical development. Journal of Autism and Developmental Disorders, 40(6), 751-761.

Boer, A., Pijl, S. J., Post, W., \& Minnaert, A. (2013). Peer acceptance and friendships of students with disabilities in general education: The role of child, peer, and classroom variables. Social Development, 22(4), 831-844.

Bollmer, J. M., Milich, R., Harris, M. J., \& Maras, M. A. (2005). A friend in need: The role of friendship quality as a protective factor in peer victimization and bullying. Journal of Interpersonal Violence, 20(6), 701-712.

Bukowski, W. M., Hoza, B., \& Boivin, M. (1994). Measuring friendship quality during pre- and early adolescence: The development and psychometric properties of the Friendship Qualities 
Scale.Journal of Social and Personal Relationships, 11(3), 471- 484. https://doi.org/10.1177/0265407594113011

Bunch, G., \& Valeo, A. (2004). Student attitudes toward peers with disabilities in inclusive and special education schools. Disability and Society, 61-76. https://doi.org/10.1080/0968759032000155640

Chang, Y., Shi, W., \& Kasari, C. (2016). Friendships in preschool children with autism spectrum disorder: What holds them back, child characteristics or teacher behavior. Autism, 20(1), 65-70.

Çiftçi, İ., \& Sucuoğlu, B. (2003). Sosyal beceri öğretimi. [Social skills training]. Ankara: Kök Yayıncılık.

Crawford, A.M., \& Manassis, K. (2011). Anxiety, social skills, friendship quality, and peer victimization: An integrated model. Journal of Anxiety Disorders, 25(7), 924-931. doi: 10.1016/j.janxdis.2011.05.005. Epub 2011 May 24

de Miguelsanz, M. M., Carbonero Martín, M. A., \& Palazuelo Martínez, M. M. (2012). Assertive skills and academic performance in primary and secondary education, giftedness, and conflictive students. Electronic Journal of Research in Educational Psychology, 10(1), 213-232.

Denham, S. A. (2006). The emotional basis of learning and development in early childhood education. In B. Spodek \& O. N. Saracho (Eds.), Handbook of Research on the Education of Young Children (2nd ed., pp. 85-99). Mahwah, New Jersey: Lawrence Erlbaum Associates.

Forness, S. and Kavale, K. (1996) Treating Social Skill Deficit in Children with Learning Disabilities: A Meta-Analysis of the Research. Learning Disability Quar- terly, 19, 2-13. https://doi.org/10.2307/1511048

Gresham, F. M., \& Elliott, S. N. (1990). Social skills rating system. Circle Pines, MN: American Guidance Service.

Gresham, F.M., \& Elliott, S.N. (2008). Social skills improvement system: Rating scales manual. Minneapolis, MN: Pearson Assessments.

Gülay, H. (2010). Okulöncesi dönemde akran ilişkileri [Peer relations in early childhood]. Ankara: Pegem Akademi Yayınları.

Guralnick, M. J. (1995). Peer-related social competence and inclusion of young children. In L. Nadel \& D. Rosenthal (Eds.), Down syndrome: Living and learning in the community (pp. 147-153). New York: Wiley-Liss.

Hadis, F. A. (2005). "Toward inclusive education in Indonesia: A country report". Paper presented at Seisa University, Ashibetsu-shi Hokkaido Japan.

Hallahan, D. P., \& Kauffman, J. M. (2006). Exceptional children: Introduction to special education (10th ed.). Boston: Allyn \& Bacon.

Han, H. S., \& Kemple, K. M. (2006). Components of social competence and strategies of support: Considering what to teach and how. Early Childhood Education Journal, 34(3), 241-246.

Heiman, T. (2000). Friendship quality among children in three educational settings. Journal of Intellectual and Developmental Disability, 25(1), 1-12. https://doi.org/10.1080/132697800112749

Hollingsworth, H. L., \& Buysse, V. (2009). Establishing Friendships in Early Childhood Inclusive Settings. Journal of Early Intervention, 31(4), 287-307. https://doi.org/10.1177/1053815109352659

Keser, I., \& Barlas, G. U. (2016). An analysis of Assertiveness Training' s effect on disabled adolescents ' self-esteem and assertiveness skills. Journal of Nursing Science, 2(5), 33-38.

Locke, J., Ishijima, E. H., Kasari, C., \& London, N. (2010). Loneliness, friendship quality and the social networks of adolescents with high-functioning autism in an inclusive school setting. Journal of Research in Special Educational Needs, 10(2), 74-81.

Ministry of National Education, (2009). Law No. 70: Inclusive Education. Jakarta: Bureau of Administration.

Nan-Zhao, Z. (2005). Four 'pillars of learning' for the reorientation and reorganization of curriculum: Reflections and discussions. International Bureau of Education-UNESCO.

Parker, J. G., \& Asher, S. R. (1993). Friendship and friendship quality in middle childhood: Links with peer group acceptance and feelings of loneliness and social dissatisfaction. Developmental Psychology, 29(4), 611-621.

Peetsma, T., Vergeer, M., Roeleveld, J., \& Karsten, S. (2001). Inclusion in education: Comparing pupils' development in special and regular education. Educational Review, 53(2), 125-135.

Petrina, N., Carter, M., Stephenson, J., \& Sweller, N. (2015). Perceived friendship quality of children with autism spectrum disorder as compared to their peers in mixed and non-mixed dyads. Journal of Autism and Developmental Disorders, 46(4). Doi: 10.1007/s10803-015-2673-5

Pijl, S.J., Frostad, P., \& Flem, A. (2008). The social position of pupils with special needs in regular schools. Scandinavian Journal of Educational Research, 52, 387-405. 
Poernomo, B. (2016). The Implementation of Inclusive Education in Indonesia : Current Problems and Challenges. American International Journal of Social Science, 5(3), 144-150.

Odom, S. L., Zercher, C., Li, S. L., Zercher, C., Li, S., Marquart, J. M., Sandall, S., \& Brown, W. H. (2006). Social acceptance and rejection of preschool children with disabilities: A mixed-method analysis. Journal of Educational Psychology, 98(4), 807-823.

Ozokcu, 0. (2018). Investigati. Peer Relationships of Children with and without Special Needs in the Preschool Period. International Journal of Early Childhood Special Education, 10(2), 92-105. DOI: 10.20489 /intjecse.506875

Republic of Indonesia. (2016). Law No. 8 Article 10: Right to Education. Jakarta: Bureau of Administration.

Richardson, P., \& Schwartz, I. S. (2004). Making friends in preschool: Friendship patterns of young children with disabilities. In B. Kryzwosz-Rynkiew \& A. Ross (Eds.), European issues on children's identity and citizenship 4: Social learning, inclusiveness and exclusiveness in Europe. Stoke on Trent, UK: Trentham Books.

Rubin, K.H., Bowker, A.K., \& Kennedy, J. (2006). Parents, peers, and social withdrawal in childhood: A relationship perspective. New Directions for Child and Adolescent Development, 127, 79-94. doi: 10.1002/cd.264

Ruijs, N., Peetsma, T., \& van der Veen, I. (2010). The presence of several students with special educational needs in inclusive education and the functioning of students with special educational needs. Educational Review, 62(1), 1-37.

Siperstein, G. N., Leffert, J. S., \& Wenz-Gross, M. (1997). The quality of friendships between children with and without learning problems.American Journal on Mental Retardation, 102(2), 111125. https://doi.org/10.1352/0895-8017(1997)102<0111:TQOFBC >2.0.CO;2

Smith K. R. M. \& Matson J. L. (2010) Social skills: differences among adults with intellectual disabilities, co-morbid autism spectrum disorders and epilepsy. Research in Developmental Disabilities, 31, 1366-1372.

Stanton-Chapman, T. L., \& Brown, T.S. (2015). Facilitating commenting and requesting skills in 3 -year-old childrem with disabilities. Journal of Early Intervention. doi/10.1177/1053815115598005.

Suleymanov, F. (2015). Issues of inclusive education: Some aspects to be considered. Electronic Journal for Inclusive Education, 3(4), 8.

Sullivan, M. C., Barcelos Winchester, S., Parker, J. G., \& Marks, A. K. (2012). Characteristic processes in close peer friendships of preterm infants at age 12. Scientifica, 2012. https://doi.org/10.6064/2012/657923

Tekinarslan, Çifci, I., Pinar, Sazak, E., Sucuoğlu, \& Bülbin (2012). Teachers' and mothers' assessment of social skills of students with mental retardation. Kuram ve Uygulamada Egitim Bilimleri

UNICEF. (2011). The Right of Children with Disabilities to Education: A Rights-Based Approach to Inclusive Education in the CEECIS Region. Diakses pada September 10, 2017, dari https://www.unicef.org/eca/Background_NoteFINAL(1).pdf

United Nations. 1994. Universal Declaration of Human Rights. Washington, DC: UN General Assembly.

Wahyuni, C. (2017). Pengaruh keterlibatan orang tua terhadap prestasi akademik siswa, dimediasi oleh keterampilan sosial siswa berkebutuhan khusus di sekolah dasar inklusif (The influence of parental involvement on students academic achievement: Mediated by the students social skills). (Unpublished master' thesis). Universitas Indonesia, Depok, Indonesia.

Wiener, J. (2002). Friendship and social adjustment of children with learning disabilities. In B. Y. L. Wong \& M. L. Donahue (Eds.), The social dimensions of learning disabilities: Essays in honor of Tanis Bryan (p. 93-114). Lawrence Erlbaum Associates Publishers.

Wiener, J., \& Tardif, C. Y. (2004). Social and emotional functioning of children with learning disabilities: does special education placement make a difference?.Learning Disabilities Research \& Practice, 19(1), 20-32.

Wojnilower, D. A., \& Gross, A. M. (1988). Knowledge, perception, and performance of assertive behavior in children with learning disabilities. Journal of Learning Disabilities, 21(2), 109-117.

Wood, P. S., \& Mallinckrodt, B. (1990). Culturally sensitive assertiveness training for ethnic minority clients. Professional Psychology: Research and Practice, 21(1), 5-11. https://doi.org/10.1037/07357028.21.1.5

Yoleri, S., \& Seven, S. (2014). Analyzing effect of age and sex differences on prosocial behavior of preschool children. International Journal of Social Science, 29, 261-270. 